\title{
Fabrication of an Electrochemical Immunosensor Containing Au-Ag Alloy for the Detection of Alpha Fetoprotein
}

\author{
Shilong Yu ${ }^{1}$, Xuefeng $\mathrm{Wu}^{2}$, Baosheng Sun ${ }^{3}$,Wei Wu ${ }^{4}$ and Hui Wang ${ }^{1, *}$ \\ ${ }^{1}$ Interventional Center, Jilin Cancer Hospital, No. 1018 Huguang Rd, Chaoyang, Changchun, 130012, \\ P.R. China \\ ${ }^{2}$ Clinical Laboratory, Jilin Cancer Hospital, No. 1018 Huguang Rd, Chaoyang, Changchun, 130012, \\ P.R. China \\ ${ }^{3}$ Radiotherapy Four Branch, Jilin Cancer Hospital, No. 1018 Huguang Rd, Chaoyang, Changchun, \\ 130012, P.R. China \\ ${ }^{4}$ Department of Radiology, Jilin Cancer Hospital, No. 1018 Huguang Rd, Chaoyang, Changchun, \\ 130012, P.R. China \\ *E-mail: wang_hua0924@qq.com
}

doi: $10.20964 / 2017.11 .02$

Received: 12 June 2017 / Accepted: 3 September 2017 / Published: 12 October 2017

\begin{abstract}
This study presented the enzyme-free determination of alpha fetoprotein (AFP) using a new electrochemical immunosensor. Our proposed immunosensor consisted of a sandwich system involving catalytic $\mathrm{Au}-\mathrm{Ag}$ nanocrystals. The determination of AFP in the absence of an enzyme was achieved through the generation of signals by the remarkable $\mathrm{Au}-\mathrm{Ag}$ alloy-induced catalysis of hydrogen peroxide reduction and the increase in sensitivity by enhanced charge transfer. Our developed immunosensor exhibited a linear range as broad as $0.05-30 \mathrm{ng} / \mathrm{mL}$ and a limit of detection (LOD) as low as $0.007 \mathrm{ng} / \mathrm{mL}$. This immunosensor was found to be sensitive for clinical determination due to its simplicity and the involvement of catalytic $\mathrm{Au}-\mathrm{Ag}$ nanoparticles.
\end{abstract}

Keywords: Electrochemical immunosensor; Enzyme-free; $\mathrm{Au}-\mathrm{Ag}$; Alpha fetoprotein; Clinic detection

\section{FULL TEXT}

(C) 2017 The Authors. Published by ESG (www.electrochemsci.org). This article is an open access article distributed under the terms and conditions of the Creative Commons Attribution license (http://creativecommons.org/licenses/by/4.0/). 